\title{
In the eye of the storm: the mental health situation of PhD candidates
}

\author{
Lucille M. S. Mattijssen · Josephine E. Bergmans · Inge C. M. van der Weijden · J. Christine Teelken
}

Received: 10 November 2020 / Revised: 18 November 2020 / Accepted: 23 November 2020 / Published online: 15 December 2020

(C) The Author(s) 2020

Completing a $\mathrm{PhD}$ is internationally considered the highest level of education that individuals can attain. It is a challenging process, that is known to be accompanied by high levels of stress, pressure and also loneliness. Despite this, until a couple of years ago, evidence about the mental health issues of $\mathrm{PhD}$ candidates often remained limited to anecdotal evidence. In recent years, more and more research is being carried out concerning the wellbeing of $\mathrm{PhD}$ candidates, as in this issue by Kusurkar et al. [1]. Going from anecdotal evidence, various studies have structurally collected both quantitative and qualitative data concerning $\mathrm{PhD}$ wellbeing. These studies have helped to falsify the past "low-stress" image of universities, and in contrast confirmed that the wellbeing of PhD candidates and early career researchers is of serious concern. Research by Levecque et al. [2] shows that $32 \%$ of $\mathrm{PhD}$ candidates in Belgium are at risk of developing mental health problems related to stress. The PhD Candidate Network Netherlands (PNN) conducted a survey amongst $1600 \mathrm{PhD}$ candidates between March and May 2020, a period during a so-called intelligent lockdown to prevent the spread of COVID-19, which meant that more sectors were

Editor's note: This commentary article refers to the article available online at https://doi.org/10.1007/s40037-02000637-6.

\section{M. S. Mattijssen \\ Department of Sociology, Vrije Universiteit Amsterdam, Amsterdam, The Netherlands}

J. E. Bergmans · I. C. M. van der Weijden $(\bowtie)$

Center for Science and Technology Studies, Leiden

University, Leiden, The Netherlands

i.c.m.van.der.weijden@cwts.leidenuniv.nl

\section{J. C. Teelken}

Department of Organization Sciences, Vrije Universiteit Amsterdam, Amsterdam, The Netherlands open than in other countries with stricter lockdown. This survey showed that no less than $47 \%$ of $\mathrm{PhD}$ candidates in the Netherlands were at risk of developing a psychiatric disorder, 39\% showed severe symptoms of burnout and $40 \%$ experienced a high or very high workload [3]. Research published in Nature in 2019 [4] regarding $6300 \mathrm{PhD}$ candidates from all over the world found that $36 \%$ of PhD candidates had sought help for anxiety or depression caused by their PhD trajectory. Combined, these studies confirm that mental health problems are widespread during the PhD trajectory, and not limited to specific countries or contexts.

These studies also identify factors that influence the mental wellbeing of $\mathrm{PhD}$ candidates. In a comprehensive overview of 163 studies on $\mathrm{PhD}$ candidate wellbeing, Sverdlik et al. [5] identified four main external factors (supervision, personal life, departmental structures and financial opportunities) and five main internal factors (motivation, writing skills, academic identity, self-worth and self-efficacy) that influence PhD wellbeing. The PNN survey [3] furthermore found international $\mathrm{PhD}$ candidates to be more at risk of mental health problems compared to their domestic colleagues. Some studies look outside the workplace for potential factors that may negatively impact the mental wellbeing of PhDs. Van der Weijden and Bergmans [6], for instance, showed that PhD candidates in the Netherlands who give informal care (almost 30\%) to a loved one develop feelings of constant strain, inability to overcome difficulties, and sleeping problems. The combination of informal care responsibilities, doing a doctoral study and having private and family life at the same time could result in mental health problems, as 55\% of informal caregiving $\mathrm{PhD}$ candidates were at risk of developing a psychiatric disorder. 
This study by Kusurkar et al. [1] complements these existing findings in two ways. First of all, most other research focuses mainly on stressors and risks factors. While one could say that the opposite of stressors are mitigators (e.g. get rid of bad work-family balance, have a good supervisor rather than a bad one, stop being unmotivated), Kusurkar et al. [1] start from the positive side and ask $\mathrm{PhD}$ candidates explicitly about moderating factors and factors that energize their $\mathrm{PhD}$ study. In this way, the focus lies more on what $\mathrm{PhD}$ candidates should do rather than what they should not. Experiencing affiliation with colleagues, focusing on concrete achievements and intrinsic motivation are the most frequently listed energizers. Secondly, the researchers investigate the interplay between various factors, exposing the mechanisms via which both stressors and energizers affect the various dimensions of burnout and how these are interrelated.

Due to these studies, $\mathrm{PhD}$ candidate wellbeing is getting more and more attention from stakeholders and policy makers. More and more universities and medical centers have implemented policies aiming to improve the mental wellbeing of $\mathrm{PhD}$ candidates and early career researchers, offering various forms of support and training. However, attention to $\mathrm{PhD}$ wellbeing is not limited to local institutions. At the international level, the OECD Global Science Forum (2019-2020) is now conducting a project that aims to reduce the precarity of research careers. The main purposes are to identify policies and procedures that could support better strategic planning and management of research careers, while increasing the wellbeing of researchers and the quality of their research. Though this project focuses mostly on postdocs, improvements resulting from this project are likely to be helpful for $\mathrm{PhD}$ candidates as well.

These recent efforts to improve the mental wellbeing of $\mathrm{PhD}$ candidates have gained even more importance since the outbreak of COVID-19 and the measures aimed to prevent further spread of the virus. Candidates experience delays in their projects due to the closing down of research facilities, difficulties in pursuing data collection, an inability to do fieldwork or a struggle to work from home due to care duties, suboptimal home working conditions or worries about the pandemic [3]. In these times, this research field offers institutions insights into how they can help their $\mathrm{PhD}$ candidates and early career re- searchers to get through these difficult times. However, as these times are unprecedented, additional research is required to identify whether the pandemic has impacted the wellbeing of $\mathrm{PhD}$ candidates, either positively or negatively, and which factors can help to (re)generate resilience, ensuring that they can successfully and healthily complete their trajectories.

Open Access This article is licensed under a Creative Commons Attribution 4.0 International License, which permits use, sharing, adaptation, distribution and reproduction in any medium or format, as long as you give appropriate credit to the original author(s) and the source, provide a link to the Creative Commons licence, and indicate if changes were made. The images or other third party material in this article are included in the article's Creative Commons licence, unless indicated otherwise in a credit line to the material. If material is not included in the article's Creative Commons licence and your intended use is not permitted by statutory regulation or exceeds the permitted use, you will need to obtain permission directly from the copyright holder. To view a copy of this licence, visit http://creativecommons.org/licenses/by/4.0/.

\section{References}

1. Kusurkar RA, Van der Burgt S, Ulviye I, Mak-Van der Vossen M, Wilschut J, Wouters A, et al. Burnout and engagement among $\mathrm{PhD}$ students in medicine: the BEeP study. Perspect Med Educ. 2020. https://doi.org/10.1007/ s40037-020-00637-6.

2. Levecque K, Anseel F, De Beuckelaer A, Van der Heyden J, Gisle L. Work organization and mental health problems in PhD students. Res Policy. 2017;46:868-79.

3. Mattijssen L, Van Vliet N, Van Doorn T, Kanbier N, Teelken C. PNN PhD Survey: Asking the relevant questions. Mental wellbeing, workload, burnout, research environment, progress of the $\mathrm{PhD}$ project, considering to quit. Promovendi Netwerk Nederland. 2020. https://hetpnn.nl/ wp-content/uploads/2020/08/PNN-PhD-Survey-reportWellbeing.pdf. Accessed 29 Oct2020.

4. Woolston C. PhDs: the tortuous truth. 2019. https:// www.nature.com/articles/d41586-019-03459-7. Accessed 13 Nov 2019.

5. Sverdlik A, Hall NC, McAlpine L, Hubbard K. The PhD experience: a review of the factors influencing doctoral students' completion, achievement, and well-being. Int J DrStud. 2018;13:361-88.

6. Bergmans J, Van der Weijden I. PhD candidates as informal caregivers in the Netherlands. 2020. https://www. cwts.nl/news?article=n-r2y2a4\&title=phd- candidates-asinformal-caregivers-in-the-netherlands. Accessed 12 Mar 2020. 